\title{
ОКРЕМІ ПИТАННЯ ДЕТЕРМІНАЦІЇ ВУЛИЧНИХ КРАДІЖОК У СІЛЬСЬКІЙ МІСЦЕВОСТІ
}

\author{
БЕЛІКОВ Костянтин Аркадійович - заступник Криворізького міського \\ голови \\ ПРИХОДЬКО Андрій Андрійович - кандидат юридичних наук, викладач \\ кафедри оперативно-розшукової діяльності Донецького юридичного інституту \\ МВС України
}

DOI:10.32782/NP.2019.4.12

УДК 343.851

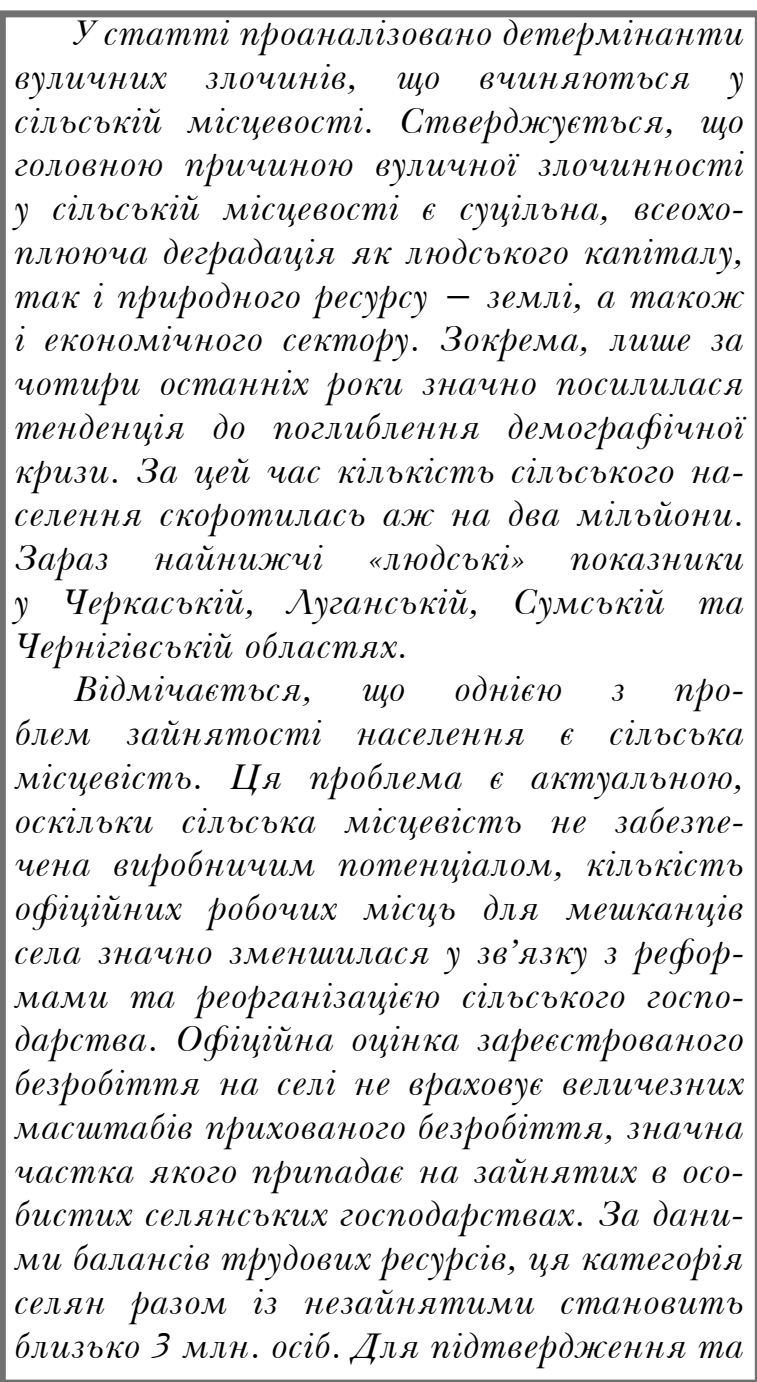

Проблема детермінації злочинності в цілому, окремих іiі видів і конкретного злочину є однією $з$ центральних проблем спростування окремих наукових положень наводяться результати проведеного анкетування.

Також розглядається негативні тендениії розвитку моральності та духовності як окремі причини вуличних крадіжок у сільській місиевості. Стверджується, що вивчення детермінант сільської злочинності необхідний аналіз внутрішніх сільських умов життедіяльності людей, який дозволить виявити чинники як негативного, так $i$ позитивного впливу на злочинність, $i$ тим самим більш цілеспрямовано здійснювати попереджувальну діяльність шляхом усунення одних і стимулювання інших.

Робиться висновок, що статистика крадіжок, особливо крадіжок особистого майна, в останні роки зумовлюеться загальним погіршенням кримінологічной ситуаиіӥ в країні, у першу чергу, - майновим розшаруванням населення, зубожінням значної його частини, що $е$ основними детермінантами крадіжок, що вчиняються в сільській місцевості. Вирішення зазначеної проблеми потребує покращення життя сільського населення на державному рівні.

Ключові слова: злочин, вуличя, крадіжка, детермінанти, причини та умовu.

кримінології. Важливість даної проблеми полягає в тому, що без їі розв'язання практично неможливе ефективне запобіган- 
ня злочинності. Проблема причинності в кримінології важлива не тільки для теорії, але і для практики, так як дозволяє вести боротьбу із злочинністю не тільки силами правоохоронних органів, а також використовуючи економічні, соціальні та інші важелі, якими суспільство і держава можуть розпорядитись. На сьогодні у кримінологічній науці відсутні як єдина термінологія у цій сфері (використовується різноманітні терміни, зокрема: детермінанти, причини та умови злочинності, фактори, чинники злочинності, джерела злочинності, обставини, що зумовлюють злочинність, тощо), так і єдина думка щодо змісту зазначених понять.

У правовій літературі різним аспектам, що стосуються проблем дослідження злочинності, у тому числі й крадіжок у сільській місцевості, приділялась увага у роботах таких науковців, як: Г.І. Балюк, Ю.Д. Блувштейн, С.В. Бобровник, М.М. Бринчук, В.В. Василевич, П.А. Воробей, С.Б. Гавриш, А.П. Гетьман, С.Г. Грицкевич, В.К. Грищук, О.М. Джужа, А.І. Долгова О.А. Дубовик, Е.М. Жевлаков, А.П. Закалюк, О.О. Кваша, В.К. Колпаков, О.М. Костенко, Н.А. Аопашенко, С.Я. Аихова, В.К. Матвійчук, П.І. Мельник, В.О. Навроцький, В.І. Осадчий, В.В. Петров, А.М. Плешаков, А.В. Савченко, В.І. Шакун, Ю.С. Шемшученко, П.Л. Фріс, Н.М. Ярмиш та ін.

Однак, не дивлячись на систематичні наукові розвідки в цій царині, окремі питання були майже залишені без уваги. Прикладом такого питання $є$ визначення причини та умов вуличних крадіжок, що вчиняються в сільській місцевості.

У зв'язку із цим, метою запропонованої статті є аналіз детермінації вуличних крадіжок, що вчиняються у сільській місцевості.

Слід зазначити, що у загальному вигляді питання детермінації злочину - це питання його причин та умов. Причини злочину - внутрішня складова, яка відображає комплекс факторів, якими зумовлено вчинення суспільно небезпечного діяння. Причини злочинності знаходяться між собою в діалектичному взаємозв'язку, взаємозумовленості і взаємозалежності. Їх вивчення розкриває сутність цього негативного соціального явища, пояснюе його походження, указує, на якому соціальному грунті воно базується, від чого залежить його існування й поширення, що цьому сприяє, а що протидіє. Тільки спираючись на ці знання, можна забезпечити ефективне попередження злочинності, передбачати зміни в їі структурі й рівні, намічати і здійснювати необхідні заходи профілактики злочинних проявів. Причина породжує наслідок у реальній дійсності, а не у свідомості людей. Причинний зв'язок передбачає взаємозв'язок явищ, що знаходяться в подібному зв'язку. Взаємозв'язок причини і слідства може мати різну природу - механічну, фізичну, хімічну, психологічну, соціальну тощо. Оскільки злочинність проявляється в поведінці людей, то дія її причин має соціально-психологічний характер - вплив відповідних об'єктів, явищ, процесів на психологію, свідомість людей [1, с. 153].

Умови є другим після причин видом детермінантів кримінологічної детермінації. Їх зв'язок 3 причиною і наслідком називають обумовленим, на відміну від спричинення. Дія умови не обов'язкова, а, як правило, ймовірна. Умова не породжує наслідок, але вона забезпечує (сприяє, допомагає) прояву та дії причини [2, с.188]. Відмінність умов від причин полягає в тому, що причина $\epsilon$ активно діючим явищем, процесом, а умова $є$ чимось пасивним, причому причина тільки у взаємодії 3 умовою призводить до появи наслідку. Відтак, умовами злочинності слід вважати такі об'єктивні обставини суспільної дійсності, які самі по собі не породжують злочинність, але «відкривають шлях» для дії причин, полегшують настання суспільно небезпечних наслідків [3, с.79-80]. Отже, можна сказати, що умови злочинності - 3овнішні чинники, які сприяють вчиненню злочину та настанню бажаних наслідків. Тобто умова є своєрідним провідником між причиною та наслідками злочину.

B.M. Кудрявцев зазначає, що умови у сукупності 3 причинами створюють так звану повну причину того чи іншого 


\section{Кримінальне право, кримінальний процес та криміналістика}

явища [4, с.17]. Причина діє тільки за наявності певних умов. Тільки взаємодія і взаємозв'язок причин та умов породжують наслідок. Умова - це те, від чого залежить дещо інше (зумовлене), що робить можливим наявність речі, стану, процесу [5, с.469]. Сутність умови і їі відмінність від причини полягають у тому, що це явище або процес, які самі по собі не породжують безпосередньо даний наслідок, але, супроводжуючи причину в просторі й у часі і впливаючи на неї, він забезпечує їі розвиток, необхідний для виникнення й настання наслідку, інакше кажучи, причина породжує наслідок, а умова цьому лише сприяє, забезпечуючи можливість дії причини. У цьому контексті доцільно зазначити, що сукупність причин та умов злочинів є визначним (детермінуючим) фактором, а отже, саме зазначена сукупність, на нашу думку, може називатися «детермінантами злочинності».

Злочини корисливого спрямування в значній частині своїх випадків пов'язані iз зубожінням громадян. Очевидно, що боротьба 3 «бідною» злочинністю вимагає суттєвого вирівнювання рівня життя в межах держави [6, с. 154]. Сдине визначення, яке можна сьогодні дати тим процесам, що набули системних, загрозливих масштабів, а можливо, й незворотного характеру - суцільна, всеохоплююча деградація як людського капіталу, так і природного ресурсу - землі, а також і економічного сектору. Зокрема, лише за чотири останніх роки значно посилилася тенденція до поглиблення демографічної кризи. За цей час кількість сільського населення скоротилась аж на два мільйони. Зараз найнижчі «людські» показники у Черкаській, Ауганській, Сумській та Чернігівській областях.

За даними досліджень вітчизняних науковців, якщо протягом 1993-2005 pр. чисельність сільського населення щороку скорочувалася на 132 тис. осіб, то на даний період - на 200 тис. Внаслідок цього в Україні вже налічується 8 тис. сіл, що втратили можливість самовідтворення населення. Автори зауважують, що звуження бази відтворення сільського населення, наростання депопуляційних процесів на початку XXI ст. соціологи та економісти пов'язують з надмірним відпливом селян у міста у другій половині 1960-х років. Значно зросла також і їх трудова міграція: понад 40\% жителів села, які працюють на підприємствах і організаціях, зайняті за межами села. Кілька мільйонів українських селян виїхали на заробітки в інші країни. Міграція сільського населення посилюється тенденцією скорочення зайнятості його у сільському та лісовому господарстві [7, с. 24]. Критично деформована також вікова структура селян: частка осіб працездатного віку становить лише 53\%, більша частина з яких - передпенсійного віку [8, с.9].

Слід зауважити, що однією з проблем зайнятості населення $\varepsilon$ сільська місцевість. Ця проблема є актуальною, оскільки сільська місцевість не забезпечена виробничим потенціалом, кількість офіційних робочих місць для мешканців села значно зменшилася у зв'язку з реформами та реорганізацією сільського господарства. Офіційна оцінка зареєстрованого безробіття на селі не враховує величезних масштабів прихованого безробіття, значна частка якого припадає на зайнятих в особистих селянських господарствах. За даними балансів трудових ресурсів, ця категорія селян разом із незайнятими становить близько 3 млн. осіб.

Для оцінки рівня життя населення в Україні та формування відповідних програм держава встановлює прожитковий мінімум, тобто вартісну величину достатнього для забезпечення нормального функціонування організму людини набору продовольчих і непродовольчих товарів і послуг [9]. Економічна та фінансова криза створила несприятливі умови щодо подальшого розвитку соціальної інфраструктури села. Через фінансову скруту розбудова поселенської мережі із року в рік катастрофічно скорочується й сьогодні майже повністю призупинилася. Руйнуються створені за тривалий період соціальні потужності на селі [10, с.110]. На сьогодні в сільському господарстві значно зменшилась кількість зайнятих у селянських фер- 
мерських господарствах, що призвело їх до несприятливих умов життя. Селянські фермерські господарства перебувають у приватній власності, що майже не впливає на чисельність зайнятих, оскільки більшість 3 них у стані вимушеної неповної зайнятості та має значну заборгованість по заробітній платі [11]. Зазначене підтверджує і проведене нами опитування. Так, на питання: «Що було головним джерелом Вашого існування до засудження?» 86 осіб відповіли, що головним джерелом доходу для них була робота у приватних підприємствах сільської місцевості; 113 осіб займалися індивідуальною трудовою діяльністю; 98 осіб мали колишні заощадження; 55 осіб жили за рахунок допомоги родичів та друзів; 35 осіб займалися стабільною незаконною діяльністю (в тому числі злочинною), 54 особи мали випадкові заробітки. Відповідно до досліджуваних кримінальних справ, серед осіб, які вчинили крадіжку в сільській місцевості, було 149 службовців, 41 підприємець, 165 селян, 98 учнів, 173 студента та 15 пенсіонерів.

Проблеми забезпечення сільського населення школами, дитячими садками, лікарнями, клубами, бібліотеками та іншими об'єктами соціальної інфраструктури загострюються. Нині в Україні одна лікарня обслуговує в середньому 39 сіл, дитячий садок - три села, школа, фельдшерсько-акушерський пункт, 97,3\% загальної кількості сіл не мають будинків побуту та комплексних приймальних пунктів, 92,7\% - лазень. Незважаючи на таку ситуацію, капітальні вкладення в соціальне будівництво на селі і мережа об’єктів соціальної інфраструктури продовжують скорочуватися. Водночас рівень задоволення жителів села соціальними послугами суттєво знижується [12, с. 111$]$.

Розвиток моральності та духовності є невід'ємною частиною виховання людини. Ще під час навчання у загальних закладах освіти діти починають вивчати основи етики та естетики, знайомитись 3 культурологією, проводити класні часи із залученням церковних служителів. На сьогодні не можна казати про те, що нашою державою церква відсунулася на другий план.
Прикладом може стати розповсюдження в’язничного капеланства, залучення священиків до політичної та військової діяльності країни тощо. Отже, наша країна намагається докладати зусиль до розвитку культури, однак у сільській місцевості це викликає низку проблем, серед яких: відсутність необхідних приміщень для культурних заходів, висока зайнятість більшості населення, низький рівень освіченості останнього, що призводить до відсутності зацікавленості в освітніх заходах.

Варто зазначити, що інколи відсутність духовності в людині призводить до того, що особа вчиняє майновий злочин безпосередньо на території храмів. Духовне виховання неповнолітніх $\epsilon$ дуже важливим, оскільки останні ще не мають сталої психіки та системи якостей та моральних цінностей, у зв'язку із чим знаходяться на межі між правомірною та протиправною поведінку, а тому упущення у їх вихованні можуть призвести до становлення дорослого злочинця.

У більшості робіт, присвячених проблемам кримінології і особливо питанням причин правопорушень, можна завжди віднайти вказівку щодо взаємозв'язку низького рівня культури із антигромадською поведінкою (О. А. Герцензон,I.I. Карпець, Б.М. Кудрявцев, Н.Ф. Кузнєцова, Г.М. Міньковський, О.Б. Сахаров, O.С. Шляпочников і інші). В умовах переходу до ринкової економіки наша держава неспроможна фінансувати в повному обсязі культурну сферу нашого життя. Ринок заполонили низькопробні твори мистецтва - фільми, книги, естрада. Така продукція зовсім не сприяє підвищенню духовності суспільства, а навпаки, призводить до спустошеності, насамперед молоді, яка некритично сприймає такі витвори. В умовах переходу до ринкової економіки наша держава не спроможна фінансувати в повному обсязі культурну сферу нашого життя. Ринок заполонили низькопробні твори мистецтва - фільми, книги, естрада. Така продукція зовсім не сприяє підвищенню духовності суспільства, а навпаки, призводить до спустошеності, насамперед молоді, 
яка некритично сприймає такі витвори [6, c.98].

На думку В. М. Кудрявцева, до суб'єктивних факторів слід віднести те i тільки те, що входить до свідомості правопорушника чи в інший спосіб характеризує його особистість. Отже, суб'єктивні причини правопорушень - це певні елементи соціальної психології, що знаходять своє відображення у спотворених потребах, інтересах, цілях, мотивах, моральних цінностях та правосвідомості осіб, які вчиняють злочини. Суб'єктивними причинами й умовами вважаються ті детермінанти злочинності, які залежать від діяльності людей і виступають, як правило, наслідком недоліків цієї діяльності, помилок і недоглядів. До суб'єктивних детермінант також відносять погляди, традиції, звички [13, с. 154]. Традиції, звичаї, звички - це сукупність досвіду народу, окремих його груп, що передається 3 покоління в покоління. За своїм змістом вони можуть бути і позитивними, і негативними. Одні з них по мірі розвитку суспільства змінюються, наповнюються новим змістом, інші долаються активними зусиллями суспільства, треті свято оберігаються кожним новим поколінням у незмінному вигляді. Їх дія на конкретні форми поведінки, у тому числі і на протиправні, очевидна. Тому в процесі профілактики злочинів у сільській місцевості необхідно враховувати вплив існуючих традицій, звичаїв, звичок з тим, щоб стимулювати одні і усувати негативну дію інших.

Значною мірою на кримінологічну обстановку в селі впливає характер взаємин між людьми, який, як правило, залежить не тільки від ступеня спорідненості його жителів. Особливістю сільської місцевості є те, що, як правило, місцеві жителі добре знайомі. Тому, на думку О. В. Сорокіна, однією із детермінант вчинення крадіжок у сільській місцевості $\epsilon$ високий процент знайомств між злочинцем і потерпілим $(91,8 \%)$, що значно вище, ніж в інших злочинах [14, с. 15].

Одним iз важливих характеристик суб'єктивних причин є мотив скоєння злочину. У корисливих злочинах мотивом їх вчинення $е$ користь. Етимологічно слово «користь» походить від давньоруського «здобич». До ХIX ст. цей термін наповнився якісно новим змістом і став означати потяг до наживи, жадібність до грошей, а згодом матеріальну вигоду, прибуток, що й дотепер продовжує визначати його зміст. У сучасних словниках «користь» трактується дещо обмежено, здебільшого лише у контексті мотиву злочину. У перекладі 3 латини мотив означає рух. На сьогодні вже не викликає сумніву те, що джерелом будь-якої людської активності $є$ потреби. Потреба - це внутрішній стан індивіда, який створюється відчуттям нужди в об'єктах, необхідних для його існування та розвитку, виступає джерелом активності та характеризується єдністю суб'єктивного й об'єктивного. Водночас у кримінології набула поширення точка зору, що користь, як мотив злочинної поведінки, є прикладом безпосередньої трансформації саме матеріальних потреб [15, с.142].

Корисливий мотив, передусім, поділяється на користь та здирництво, користьнакопичення, користь-паразитизм, службова користь, користь-легковажність, користь-нужденність, що є підставою відповідного тлумачення корисливих злочинів. Так, науковці вважають, що у вузькому значенні корисливі злочини вчиняються задля задоволення так званих «відносних» потреб, які виникають в умовах соціально-економічної диференціації населення при порівнянні особистого матеріального становища зі становищем інших людей, а також задля досягнення ідеалу матеріального чи пов'язаного з ним соціального стандарту. У широкому значенні - це всі злочини, вчинені з «економічних мотивів», у тому числі й задля задоволенням так званих «абсолютних", тобто необхідних для виживання людини матеріальних потреб $[15$, с.134].

Для вивчення детермінант сільської злочинності необхідний аналіз внутрішньосільських умов життєдіяльності людей, який дозволить виявити чинники як негативного, так і позитивного впливу на злочинність, і тим самим більш цілеспря- 
мовано здійснювати попереджувальну діяльність шляхом усунення одних і стимулювання інших.

До чинників, іманентно властивих селу і які до певної міри впливають на кримінологічну обстановку в ньому, можна віднести наступні: історія виникнення, i склад жителів села, поширеність різних традицій, звичаїв, устрій життя, характер взаємин в сільському колективі, спрямованість його громадської думки, ступінь соціальної (зокрема правової) активності населення, стан і рівень організації профілактичної діяльності. Донині збереглося немало сіл, значна частина населення яких знаходиться в споріднених відносинах. У таких селах, де мало не половина жителів носить одне прізвище, найбільш тісні міжособові контакти, вищий ступінь соціального контролю, громадська думка, інтереси, конкретні форми поведінки одноманітніші. Спрямованість же цих інтересів, громадської думки, поведінки, зміст взаємин в селі залежать і від особливостей національної психології, і від ряду інших чинників.

До детермінант соціально-економічного характеру також слід віднести: недосконалість та слабку розвиненість сільської ринкової інфраструктури; слабку фінансову та матеріально-технічну підтримку сільськогосподарських підприємств державою. Нині у процесі роздержавлення, приватизації і розпаюванні землі та майна колгоспів створюються нові сільськогосподарські підприємства. Внаслідок цього утворився кризовий платіжний стан та нестача коштів у обігу підприємств; відсутність механізмів кредитування та інвестицій сільськогосподарських підприємств. Іноземні інвестори, вкладаючи капітал у нашу економіку, надають перевагу посередництву. Значна частина виробленої спільними підприємствами продукції реалізується на внутрішньому ринку, що не лише не сприяє зростанню експорту, а й призводить до збільшення зовнішнього боргу України [23, с.189].

Таким чином, статистика крадіжок, особливо крадіжок особистого майна, в останні роки, зумовлюеться загальним погіршенням кримінологічної ситуації в країні, в першу чергу, - майновим розшаруванням населення, зубожінням значної його частини, що є основними детермінантами крадіжок, що вчиняються в сільській місцевості. Вирішення зазначеної проблеми потребує покращення життя сільського населення на державному рівні.

\section{Лiтература}

1. Аукашевич С. Ю. Проблема визначення причин та умов злочинності у кримінології. Проблеми злочинності : респ. між від. наук. зб.. - Х. : Нац. юрид. акад. України, 2007. Вип. 90.С. 153-156

2. Закалюк А. П. Прогнозирование и предупреждение индивидуального преступного поведения. М. : Юрид. Аит., 1986. 192 с.

3. Курило В.І., Михайлов О.Е., Яра О.С. Кримінологія: Загальна частина. Курс лекцій. Навчальний посібник. К. : Кондор, 2006. 192 c.

4. Кудрявцев В. Н. Генезис преступления. Опыт криминологического моделирования. М. : ФОРУМ-ИНФРА-М, 1998. 215 c.

5. Философский энциклопедический словарь. М. : ИНФРА-М. 1998. 576 с.

6. Медицький I. Б. Вплив соціальних факторів на злочинність в умовах становлення незалежної України: монографія. Івано-Франківськ: Прикартпат. юрид. ін.-т, 2007. 222 с.

7. Кириленко I. Г., Павленко О.I. Проблеми українського села та їх вирішення у контексті аграрних реформ. Економіка АПК. 2010. № 7. С. 24-30.

8. Саблук, П. Т. Розвиток сільських територій в контексті забезпечення економічної стабільності держави. Економіка АПК. 2005. №11. С. 4-12.

9. Закон України «Про прожитковий мінімум» від 15 лип. 1999 р. URL: http:// zakon.rada.gov.ua/cgi-bin/laws/main . cgi?nreg $=400-12$

10. Ярковий А. О., Морозок Н.В. Шляхи подолання бідності сільського населення. Економіка АПК. 2010. № 9. С. 109-113.

11. Кравчук Ю. Б. До питання про 


\section{Кримінальне право, кримінальний процес та криміналістика}

державного регулювання зайнятості сільського населення URL: http://oldconf. neasmo.org.ua/node/345.

12. Харчук С. А. Поселенська структура села та рівень її облаштованості. Економіка АПК. 2010.№ 7. С. 108-112.

13. Кудрявцев В. Н. Стратегии борьбы с преступностью. М.: Юристъ, 2003. 312 с.

14. Сорокин А.Б. Криминологичекая характеристика и предупреждение преступлений в сельской местности : дис. кандидата юрид. наук : 12.00.08. - Ростовна-Дону, 2005. - 25 с.

15. Долгова А. И. Социальнопсихологические аспекты преступности несовершеннолетних. М., 1981. 159 с.

16. Боліна С.Н. Проблеми протидії злочинності у процесі реформування власності в аграрному секторі економіки. Науковий вісник НАВСУ. 2001. № 4. С. 189191.
The article analyzes the determinants of street crimes committed in rural areas. It is argued that the main cause of street crime in rural areas is the continuous, comprehensive degradation of both human capital and natural resources - land, as well as the economic sector. In particular, over the past four years alone, the trend towards a deepening demographic crisis has intensified significantly. During this time, the number of the rural population decreased by as much as two million. Now the lowest «human» indicators in Cherkassy, Lugansk, Sumy and Chernihiv regions.

It is noted that one of the problems of employment is the countryside. This problem is urgent, since the countryside is not provided with production potential, the number of official jobs for rural residents has significantly decreased due to reforms and the reorganization of agriculture. The official estimate of registered unemployment in rural areas does not take into account the enormous extent of hidden unemployment, a significant part of which is employed in personal agriculture. According to the balance of labor resources, this category of peasants, together with the unemployed, is about 3 million people. To confirm and refute certain scientific provisions, the results of the survey.

The negative trends in the development of morality and spirituality are also considered as separate causes of street thefts in rural areas. It is argued that the study of the determinants of rural crime requires an analysis of the internal rural living conditions of people, which will allow to identify factors, both negative and positive effects on crime, and thereby more specifically carry out preventive activities by eliminating some and stimulating others.

It is concluded that the statistics of thefts, especially thefts of personal property, in recent years, is caused by the general deterioration of the criminological situation in the country, primarily, by the property stratification of the population, the impoverishment of a significant part of it, which are the main determinants of thefts committed in rural areas. The solution of this problem requires improving the life of the rural population at the state level.

Key words: crime, street, theft, determinants, causes and conditions. 